\title{
Some effects of variation in carbohydrate and nitrogen intakes on the chemical composition of mixed rumen bacteria from young steers
}

\author{
By A. B. McALLAN AND R. H. SMITH \\ National Institute for Research in Dairying, Shinfield, Reading $R G_{2}{ }_{9} A T$
}

(Received 24 November 1975 - Accepted 4 May 1976)

\begin{abstract}
I. Samples of rumen digesta were taken at different times after giving calves various dried forage or hay and cereal diets and mixed bacteria were separated.

2. For calves receiving dried forage only, the carbohydrate content of mixed bacteria varied with time after feeding, reaching a maximum of approximately $140 \mathrm{~g} / \mathrm{kg}$ dry matter (DM) after $0.5^{-1} \mathrm{~h}$, decreasing to about $60 \mathrm{~g} / \mathrm{kg} \mathrm{DM}$ after $4 \mathrm{~h}$,

3. Replacement of part of the dried forage with glucose to give a similar metabolizable energy intake but approximately half as much nitrogen, produced a similar pattern of change with time after feeding but resulted in a markedly increased maximum bacterial carbohydrate content (approximately $230 \mathrm{~g} / \mathrm{kg} \mathrm{DM}$ ). Addition of urea to this diet reduced the bacterial accumulation of carbohydrate to approximately the same level as was found in samples from calves receiving forage only diets. For the forage diets the carbohydrate content fell to $60-100 \mathrm{~g} / \mathrm{kg} \mathrm{DM} 4 \mathrm{~h}$ after feeding. For the hay and cereal diet the value was $170 \mathrm{~g} / \mathrm{kg} \mathrm{DM}$ at this time.

4. Changes in bacterial carbohydrate content were largely a result of changes in storage polysaccharide ( $\alpha$-dextran) content.

5. Crude protein $(\mathrm{N} \times 6.25)$ and ash contents of mixed bacteria decreased after feeding with all-forage diets, but returned to approximately fasting levels within $4 \mathrm{~h}$. At this time samples from calves receiving dried forage and glucose diets contained less CP and more ash (approximately 450 and $220 \mathrm{~g} / \mathrm{kg}$ DM respectively) than those from calves given diets of dried forage only (approximately 525 and $180 \mathrm{~g} / \mathrm{kg} \mathrm{DM}$ respectively).

6. CP, total carbohydrate and ash content of mixed rumen bacteria contributed approximately $0.80 \mathrm{~g} / \mathrm{g}$ DM.

7. Sodium, potassium, calcium, magnesium and phosphate accounted for approximately $0.50 \mathrm{~g} / \mathrm{g}$ bacterial ash.
\end{abstract}

Mixed bacteria contribute considerable proportions of some of the constituents entering the duodenum of ruminants and variation in their composition can be expected to lead to appreciable differences in the amounts of some nutrients received by the host. For example, the protein contents of the cells are generally the largest single source of amino acids and although the proportions of individual amino acids in the protein do not vary greatly (Purser, I970), the total amounts of protein in the cells varies considerably. Values from 0.32 to $0.57 \mathrm{~g} \mathrm{CP} / \mathrm{g}$ of the cellular DM, of which about $80 \%$ was true protein, have been reported (Smith, I975). Thus about half or more of the cellular material is made up of other constituents and some values for some of these constituents (particularly carbohydrate, nucleic acid, lipid and ash) have been reported (Hoogenraad \& Hird, 1970; Jouany \& Thivend, 1972; Bird, 1973; Smith \& McAllan, I973, 1974; McAllan \& Smith, I974; Czerkawski, 1975). However, the results for many constituents are scanty and knowledge of factors influencing their variation even more so. Some conclusions have been based upon in vitro studies and, for example, led to Walker \& Nader ( 1970 ) stating that if a feed contains a considerable 
Table I. Daily amounts* $(\mathrm{kg})$ of the components of diets given to calves weighing 90-1 I $\mathrm{kg}$

\begin{tabular}{|c|c|c|c|c|c|c|c|}
\hline Component & ra & $2 a$ & $3 \mathbf{a}$ & $\mathrm{Ib}$ & $2 b$ & $3 b$ & 4 \\
\hline Dried lucerne (Medicago sativa $\mathbf{L}$. ) & $2 \cdot 40$ & $1 \cdot 20$ & $\mathrm{I} \cdot 20$ & - & - & - & - \\
\hline $\begin{array}{l}\text { Dried tall fescue (Festuca elatior sub. } \\
\text { Arundinaceae) }\end{array}$ & - & - & - & $2 \cdot 40$ & I.20 & I:20 & - \\
\hline Glucose & - & 0.70 & 0.70 & - & 0.70 & 0.70 & - \\
\hline Urea & - & - & 0.07 & - & - & 0.07 & - \\
\hline Flaked maize & - & - & - & - & - & - & $I \cdot 26$ \\
\hline Hay & - & - & - & - & - & - & $1 \cdot 15$ \\
\hline Nitrogen ( $\mathrm{g} / \mathrm{kg}$ dry matter) & 30 & 16 & 33 & 29 & 16 & 32 & 16 \\
\hline Metabolizable energy $(\mathrm{MJ} / \mathrm{kg})$ & $8 \cdot 8$ & II $\cdot 8$ & II 8 & $10 \cdot 3$ & II.6 & II 6 & II 6 \\
\hline
\end{tabular}

amount of a readily available carbohydrate source, a large amount of the synthetic activity of the bacteria will be initially devoted to polysaccharide synthesis rather than to protein synthesis. The only reported results obtained directly for effect of diet, time after feeding and environment under in vivo conditions appear to be those of Jouany \& Thivend (1972), McAllan \& Smith (1974) and Smith \& McAllan (1974).

The present work was carried out in an attempt to provide further information on factors influencing the chemical composition of mixed rumen bacteria.

\section{METHODS}

Animals, feeding and sampling of digesta

Castrated male Friesian calves were fitted with simple rumen cannulas at 8-15 weeks of age as described by Smith \& McAllan (1970). The pre-experimental conduct of calf treatment and feeding was as described by McAllan \& Smith (1974). The calves were kept out of direct contact with adult animals under conditions described as Environment A by Smith \& McAllan (1974). Samples of rumen digesta taken throughout the experimental periods were examined microscopically for ciliate protozoa. The majority of samples contained no ciliate protozoa; in some, small numbers were observed, but none exceeded $7 \times 10^{4}$ counts $/ \mathrm{ml}$.

In experiments using cereal-roughage diets three calves aged 25-37 weeks and weighing $133^{-1} 167 \mathrm{~kg}$ were given diets of approximately equal parts of flaked maize and hay (diet 4 , Table $\mathrm{r}$ ). This diet contained $16 \mathrm{~g} \mathrm{~N} / \mathrm{kg}$ DM and provided approximately $27 \mathrm{MJ}$ metabolizable energy (ME)/d for animals at $100 \mathrm{~kg}$ body-weight. The concentrate part of the diet was given in two equal portions at 09.00 and 17.00 hours but the 'roughage' part was given only at 17.00 hours.

In initial experiments using dried forage diets three calves aged $35-53$ weeks and weighing $123-202 \mathrm{~kg}$ were given diets based on dried lucerne (Medicago sativa L., var. Europe) alone or supplemented with glucose or glucose and urea (diets ra, za and 3 a, respectively, Table 1 ). In later experiments a further two calves aged 28-46 weeks and weighing $12 \mathrm{I}-\mathrm{r} 68 \mathrm{~kg}$ were given diets based on dried tall fescue (Festuca 


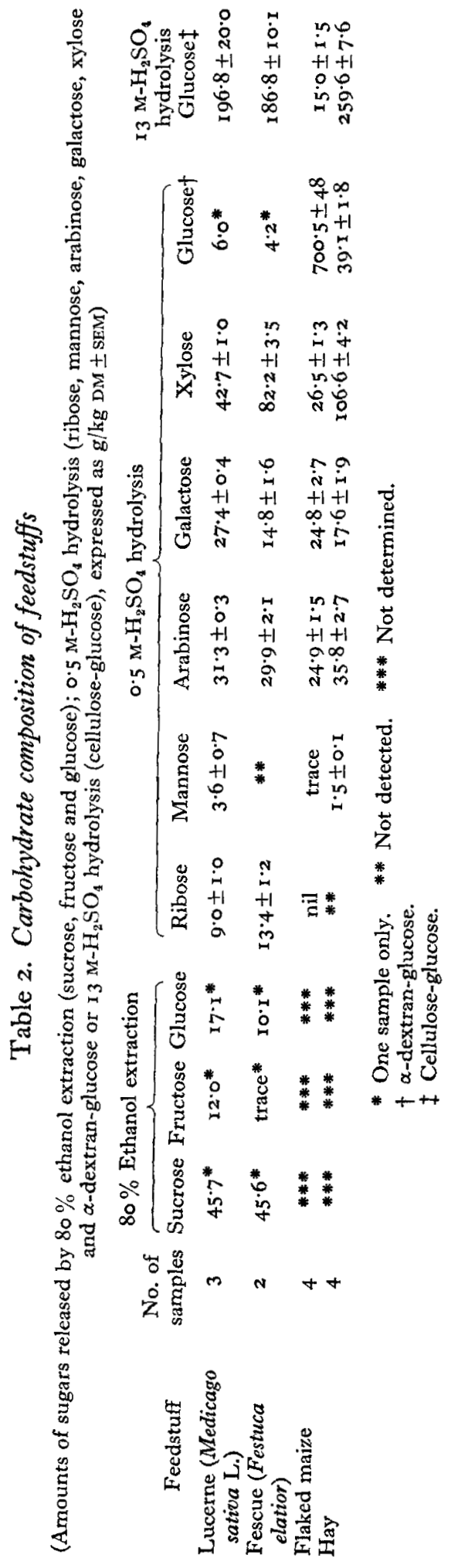


elatior sub. Arundinaceae var. $S_{1} 70$ ) alone or supplemented with glucose or glucose and urea (Diets $\mathrm{Ib}, 2 \mathrm{~b}$ and $3 \mathrm{~b}$, respectively, Table $\mathrm{I}$ ). Both dried forages contained approximately $3 \circ \mathrm{g} \mathrm{N} / \mathrm{kg} \mathrm{DM}$ and provided approximately the same amounts of ME 22-24 MJ/d for animals at $100 \mathrm{~kg}$ body weight). They were in the form of loose cobs which were broken up by hand to facilitate mixing with other dietary constituents. The diets were given in two equal portions at 09.00 and 17.00 hours. Diets were each given for a period of $21 \mathrm{~d}$ before sampling commenced. The sequence of diets was $a, b, c, b, c, a$ for both forages.

The carbohydrate compositions of the dietary constituents are presented in Table 2.

Samples of rumen digesta were collected according to the procedure of Smith \& McAllan (I970) and mixed rumen bacteria were separated as described by Smith \& McAllan (1974). Approximately I 1 of rumen digesta was required to provide a sufficient quantity of mixed bacteria for the analyses carried out. To reduce the possibility of a disturbing effect on rumen function of altering the rumen volume during the investigation, only one sample of digesta was removed from the rumen/d. Five samples were taken over a 5 -d period in the sequence: immediately prior to $(o \mathrm{~h})$ and $2,0.5,4$ and $\mathrm{I} h$ after the morning feed. After $2 \mathrm{~d}$ rest the sampling was repeated over the next $5 \mathrm{~d}$ at $2,0,4, \mathrm{x}$ and $0.5 \mathrm{~h}$ after the morning feed. Subsequent replicates were collected, as far as possible, in further different sequences. No differences were observed in any measurement attributable to the order of sampling.

Analytical methods. The dried forages contained some free sugars. These were determined by extracting with boiling $80 \%(\mathrm{v} / \mathrm{v})$ ethanol for $4 \mathrm{~h}$ and preparing carbohydrate-borate complexes which were analysed by ion-exchange chromatography (Smith \& McAllan, I97 I McAllan \& Smith, I974). Extracted forage residues and all other samples were hydrolysed in $0.5 \mathrm{M}-\mathrm{H}_{2} \mathrm{SO}_{4}$ and the liberated sugars estimated as above. Glucose released under these conditions has been shown to be present mainly in $\alpha$-linked form (McAllan \& Smith, 1974) and in the present work $\alpha$-linked glucose polymers of unknown composition are referred to as $\alpha$-dextran. Residues from the first hydrolysis were subjected to further hydrolysis in $\mathrm{I}_{3} \mathrm{M}-\mathrm{H}_{2} \mathrm{SO}_{4}$ followed by $0.45 \mathrm{M}$ $\mathrm{H}_{2} \mathrm{SO}_{4}$ and estimated by a glucose-oxidase:peroxidase procedure (McAllan \& Smith, I974). Glucose released under these conditions is referred to as cellulose-glucose. Values for total carbohydrate were obtained by summation of individual sugar concentrations.

Total $\mathrm{N}$ was estimated in Kjeldahl digests by an automated colorimetric procedure as described by Smith \& McAllan (1970). Ash values were obtained by heating ovendried samples of mixed rumen bacteria at $600^{\circ}$ for $20 \mathrm{~h}$. Calcium and magnesium were estimated by atomic absorption spectroscopy of perchloric acid digests of ashed samples according to Smith \& McAllan (1966). Sodium and potassium were estimated by flame photometry as described by Smith (1962). Phosphorus was determined as phosphate in perchloric acid digests of ashed samples by an automated colorimetric method (Technicon Methodology Sheet, Technicon Instruments Limited, Basingstoke, Hants) based on the procedure of Fiske \& Subarrow (1925). 


\section{RESULTS}

Samples of mixed bacteria were separated from rumen digesta taken $4 \mathrm{~h}$ after three calves had been given diet 4 (flaked maize and hay).

Results of analysis of chemical composition are presented in Table 3 . The carbohydrate fraction contained the following sugars generally in this descending order of abundance: $\alpha$-dextran-glucose, galactose, rhamnose, ribose and mannose with trace amounts of arabinose, xylose and cellulose-glucose. Results for the quantitatively important sugars are given in Table 4.

In initial experiments with dried forage diets, three calves were given diets Ia, 2a and 3a. Mixed bacteria were separated from rumen digesta taken $4 \mathrm{~h}$ after feeding and results of chemical analysis are presented in Table 3. Amounts of total carbohydrates found in samples from calves receiving the glucose- or glucose and urea-supplemented diets were similar to each other, but approximately double those found in bacteria from calves receiving the unsupplemented forage diets and approximately half those in samples from calves receiving cereal and roughage diets. Total amounts of the three major constituents comprised approximately $0.80 \mathrm{~g} / \mathrm{g}$ dry weight of the cells. Results for the quantitatively important sugars in the carbohydrate fraction are given in Table 4 . The order of abundance was as described for samples from calves receiving cereal and roughage diets. Variations found in the total carbohydrate content of bacterial samples from calves on different diets (Table 3) were a direct result of changes in the $\alpha$-dextran-glucose and, to a lesser extent, galactose contents of the cells.

\section{Changes in bacterial composition with time after feeding}

Results for mixed bacteria, separated from rumen digesta taken $0.5 \mathrm{~h}$ after giving one calf diets $\mathrm{ra}$ and $2 \mathrm{a}$ are also given in Tables 3 and 4 . The total carbohydrate content was considerably higher than the corresponding $4 \mathrm{~h}$ values from calves on similar diets but similar to those found in samples taken $4 \mathrm{~h}$ after giving calves cereal and roughage diets (Table 3 ). The change with time after feeding was mainly attributable to differences in $\alpha$-dextran-glucose content (Table 4). Ash and CP contents of the samples separated from digesta taken $0.5 \mathrm{~h}$ after feeding were lower than the corresponding $4 \mathrm{~h}$ samples. Results from these initial experiments indicated the need for a more detailed examination of changes occurring in mixed rumen bacterial composition with time after feeding.

Two calves were given diets $\mathrm{I} b, 2 \mathrm{~b}$ and $3 \mathrm{~b}$. Samples of mixed bacteria were separated from rumen digesta taken at various times after feeding. Results of chemical analysis are shown in Fig. I. Total carbohydrate contents of prefeed samples from all diets were low but increased rapidly after feeding and had reached a maximum value after approximately $0 \cdot 5^{-1} \cdot 0 \mathrm{~h}$. Values decreased over the next $3-4 \mathrm{~h}$. These changes in total carbohydrate content were a direct result of changes in the $\alpha$-dextran-glucose content of the cells (Fig. 2). No such marked changes were found in the total of the other sugars present, which remained at $30-50 \mathrm{~g} / \mathrm{kg}$ bacterial DM for all diets. Minor variations in these amounts were generally a result of changes in the galactose content. 
60

A. B. McAllan and R. H. Smith

1977

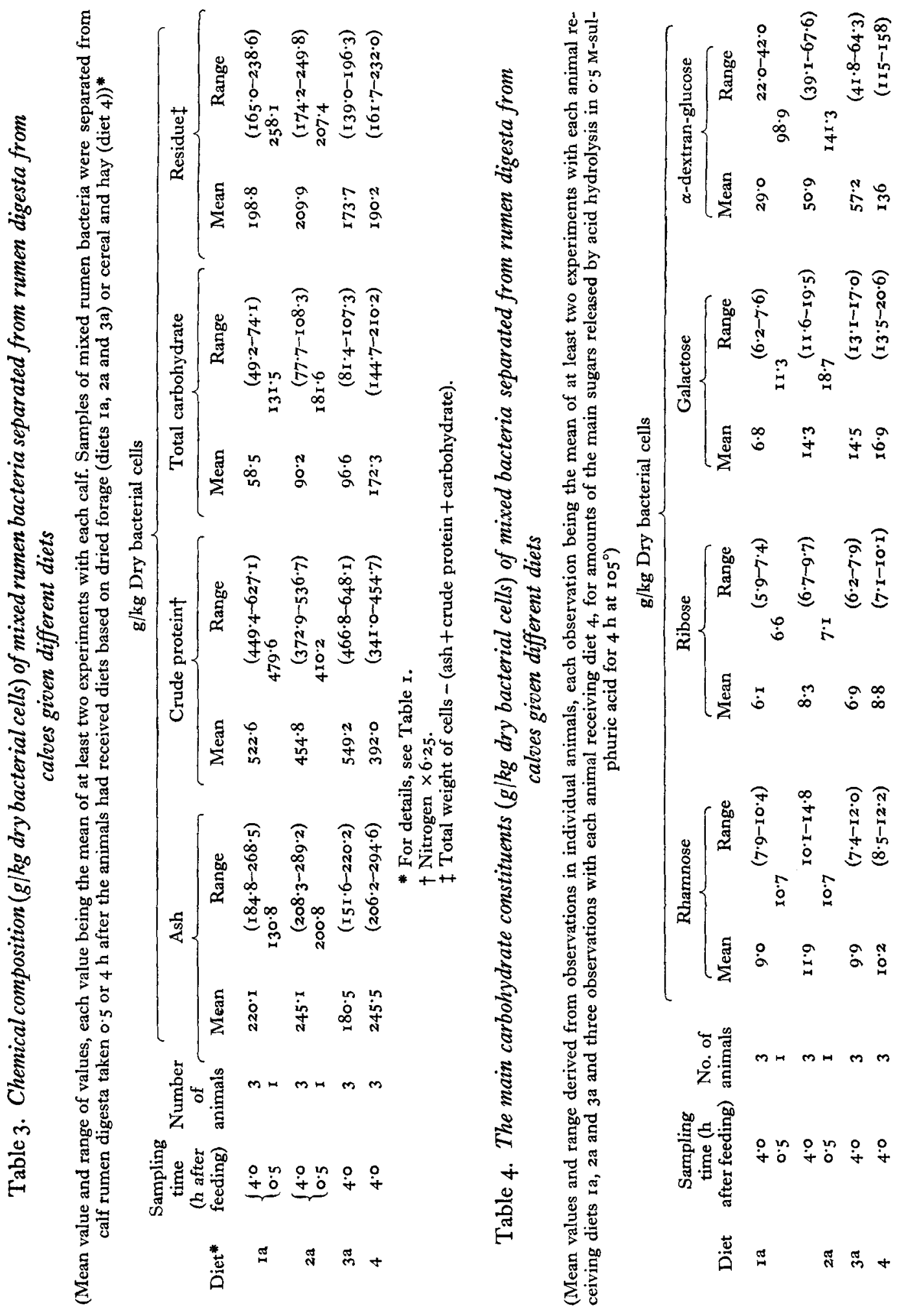




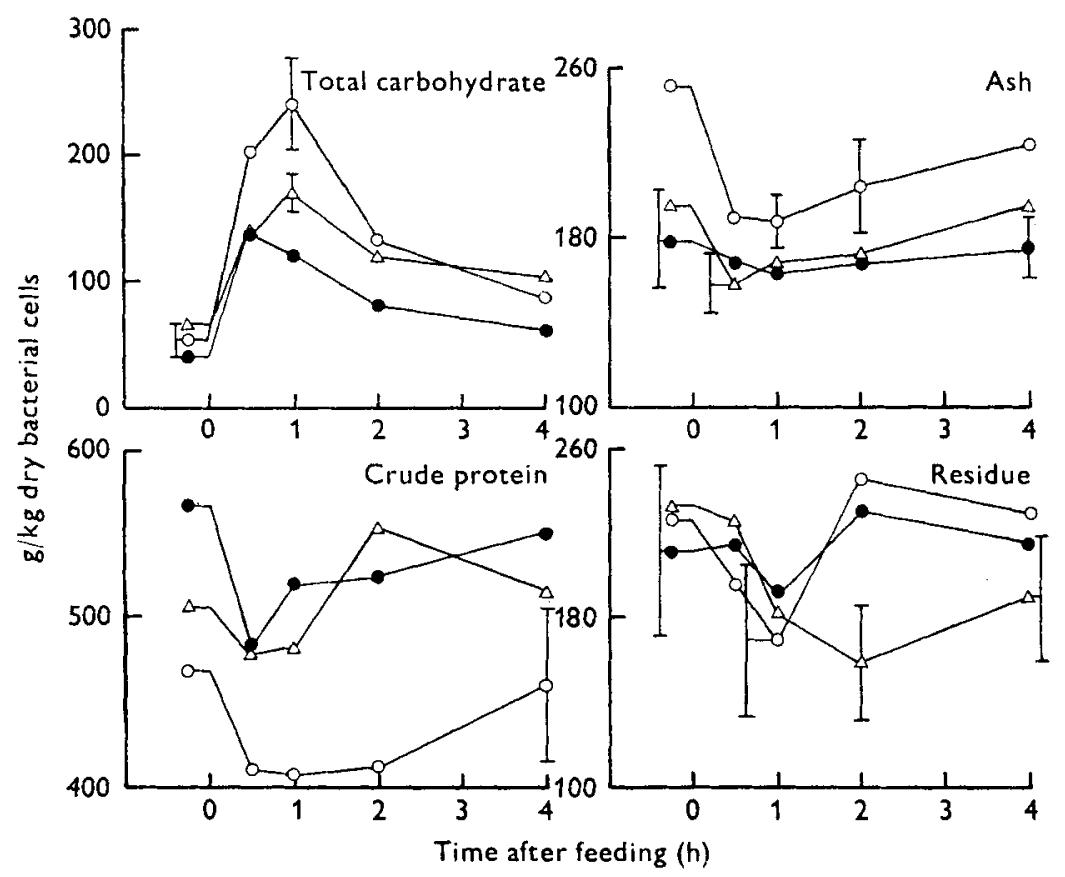

Fig. 1. Changes, with time after the morning feed, in the chemical composition of mixed rumen bacteria separated from rumen digesta samples from calves ( $\mathrm{g} / \mathrm{kg}$ dry bacterial cells) taken at different times after feeding diets based on dried fescue alone (O); with glucose $(O)$ or with glucose and urea $(\triangle)$ for details see Table 1 . Mean values from two calves (four experiments with each calf), with their standard errors represented by vertical bars only when this exceeds $10 \%$ of the total.

Prefeed concentrations of both bacterial $\mathrm{CP}$ and ash (Fig. I) varied between diets. The CP content was highest in samples from calves receiving diet $2 \mathrm{~b}$ (dried fescue and glucose) and lowest in samples from calves receiving diet $\mathrm{rb}$ (dried fescue only), but the reverse was true for ash contents. In samples from these fescue diets the concentrations of both bacterial $\mathrm{CP}$ and ash decreased after feeding reaching minimum values after $0.5^{-\mathrm{I}} \cdot \mathrm{Oh}$ and thereafter increased to approximately prefeed levels by about $4 \mathrm{~h}$ (Fig. r). Total amounts of carbohydrate, $\mathrm{CP}$ and ash normally accounted for between 0.75 and $0.85 \mathrm{~g} / \mathrm{g}$ dry weight of the cells. The residual material (obtained by difference) varied, with time after feeding, in a similar manner to the CP and ash contents.

The chemical composition of bacterial samples separated from digesta taken $0 \cdot 5$ and $4 \mathrm{~h}$ after giving a feed of diets $\mathrm{Ib}, 2 \mathrm{~b}$ or $3 \mathrm{~b}$ (Figs $\mathrm{I}$ and 2 ), were similar to those of samples taken at similar times from the calves receiving diets $1 \mathrm{a}, 2 \mathrm{a}$ or $3^{\mathrm{a}}$ (Tables 3 and 4).

\section{Mineral composition of bacterial ash}

Variations found in the ash content of mixed bacteria were associated with some changes in the mineral composition. Results indicating the contribution of some of the major minerals to total bacterial ash are shown in Fig. 3. The $\mathrm{Na}$ and, to lesser extents, $\mathrm{K}$ and $\mathrm{P}$ contents varied in bacteria from calves receiving different diets and also 


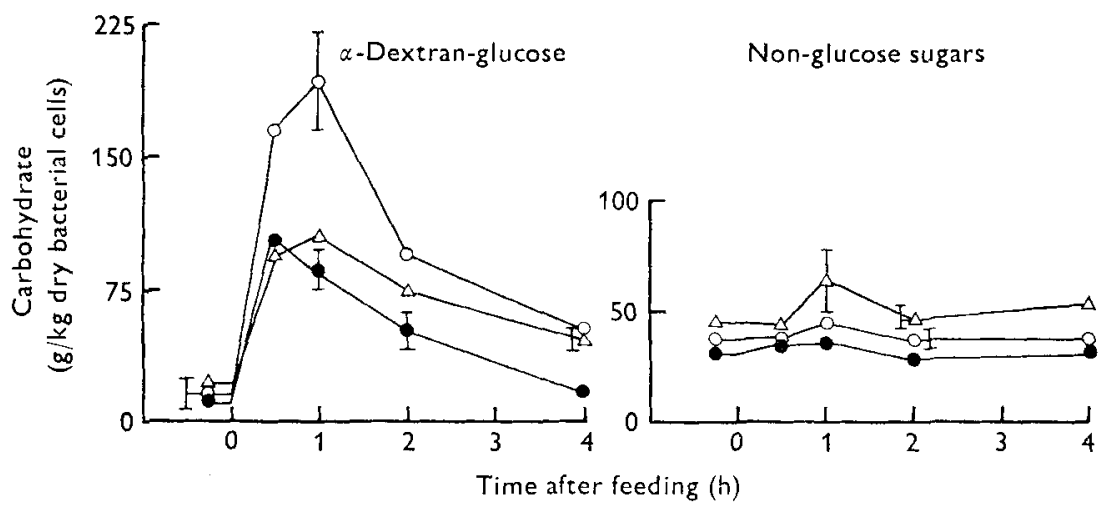

Fig. 2. Changes, with time after the morning feed, in the carbohydrate constituents $(\mathrm{g} / \mathrm{kg}$ dry bacterial cells) of mixed rumen bacteria separated from rumen digesta samples from calves taken at different times after feeding diets based on dried fescue alone ( $\bullet$ ), with glucose $(O)$ or with glucose and urea $(\Delta)$ for details of diets see Table I. Mean values from two calves (four experiments with each calf) with their standard errors represented by vertical bars only when this exceeds $10 \%$ of the total.
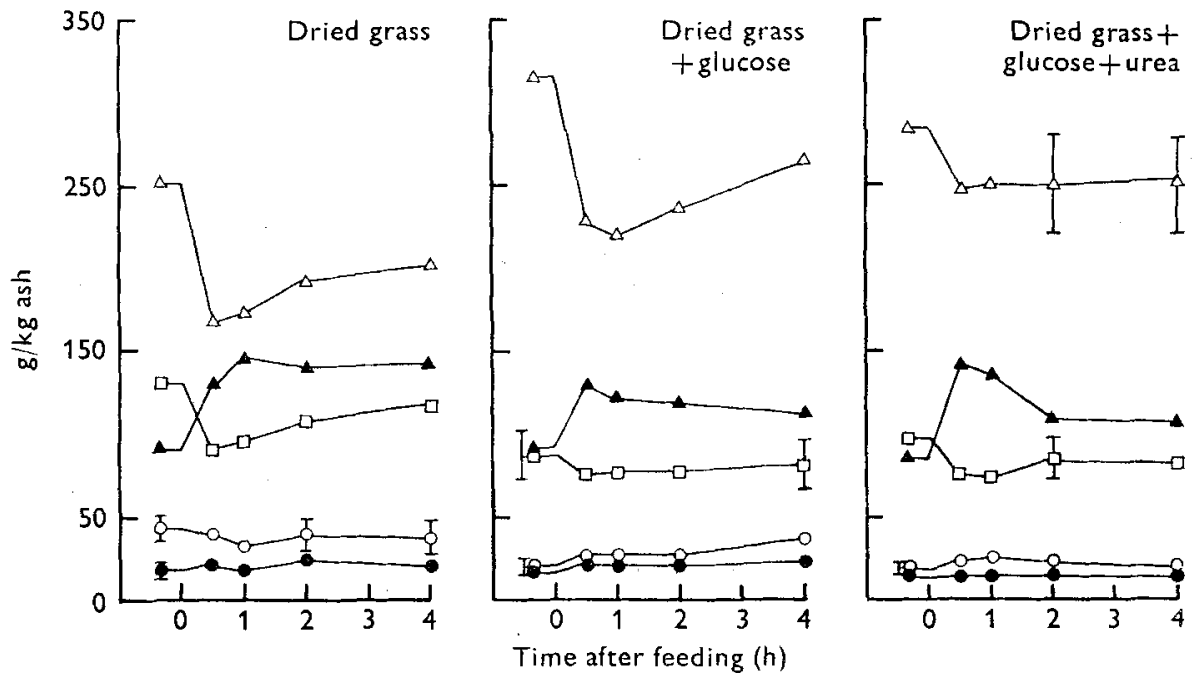

Fig. 3. Changes with time after the morning feed in some mineral constituents $(\mathrm{g} / \mathrm{kg}$ bacterial ash) of mixed rumen bacteria separated from rumen digesta samples from calves, talsen at different times after feeding. Samples were ashed as described on p. 58 and analysed for sodium $(\triangle)$, potassium $(\boldsymbol{\Lambda})$, phosphate $(\square)$, calcium $(\bigcirc)$ and magnesium $(\boldsymbol{O})$. Mean values from two calves (four experiments with each calf) with their standard errors represented by vertical bars only when this exceeds $10 \%$ of the total.

changed with time after feeding. Little or no change was found in either the $\mathrm{Ca}$ or $\mathrm{Mg}$ contents, either with diet or time of sampling. The minerals analysed generally comprised approximately $0.50 \mathrm{~g} / \mathrm{g}$ bacterial ash.

\section{DISCUSSION}

The average chemical composition of a mixed bacterial population in the rumen depends upon many different factors. Type of diet (Bryant, 1973) and the presence of 
protozoa (Eadie \& Hobson, I962; Coleman, 1964, 1972; Eadie \& Gill, 1971) may affect the numbers and types present in rumen fluid at any one time and the metabolic activities of individual species may be influenced by different conditions such as $\mathrm{pH}$ (Hobson, I965), the presence of protozoa (Kurihara, Eadie, Hobson \& Mann, I968) and the nutrients available (Herbert, 196r).

In an earlier study (McAllan \& Smith, 1976) observed differences between samples of similar nutritional status, which presumably reflected mainly species differences, included an inverse correlation between protein and ash contents of mixed rumen bacteria. Samples taken before a morning feed in the present work, which were probably all in a similar nutritional state (indicated, for example, by the fact that all contained similar and low amounts of carbohydrate (Fig. I)) showed considerable differences in protein and ash contents which were correlated in this way. Whatever this initial composition, however, when the host animals were given feeds based on forage the subsequent changes in rumen bacterial composition although different in extent were always of a similar pattern (Fig. I). Thus there was a peak in carbohydrate accumulation at $0^{\circ} 5^{-1} \cdot \mathrm{O}$ after feeding which was followed by a rapid decline and changes in $\mathrm{CP}$, ash and residue contents which could largely be explained as the result of simple dilution by the accreted carbohydrate. These changes in bacterial carbohydrate were mainly due to changes in a component, presumably a labile energy store, which released glucose on mild acid hydrolysis indicating that it was an $\alpha$ linked glucose polymer. The detailed structure of this compound is unknown and it has therefore been referred to simply as $\alpha$-dextran. It is not known to what extent this compound is stored intracellularly or as an extracellular accretion.

It is unlikely that cellulose digestion could have been responsible for the rapid transient accumulation of $\alpha$-dextran after forage feeding (Jouany \& Thivend, 1972). It seems more probable that this was supported largely by the readily available sugars present in the unsupplemented forage and by the glucose supplement when this was included. These changes in bacterial $\alpha$-dextran accumulation for the forage-based diets were quite different in pattern from those seen in the rumen bacteria of calves given starch-containing diets (McAllan \& Smith, 1974). In the latter the $\alpha$-dextran accumulation increased steadily up to about $4 \mathrm{~h}$ after feeding and then remained fairly constant for at least a further $2 \mathrm{~h}$. Although this pattern was not examined in detail in the present work the values given in Table 4 for samples taken $4 \mathrm{~h}$ after feeding were consistent with it.

Adding supplementary dietary nitrogen compounds reduced bacterial $\alpha$-dextran accumulation both in animals given starch based diets (McAllan \& Smith, 1974), and forage and glucose diets (Fig. I) but the respective patterns of $\alpha$-dextran accumulation with time remained essentially unchanged.

Differences in bacterial $\alpha$-dextran accumulation, such as those observed between starch and sugar-containing diets and between diets providing different $\mathrm{N}$ intakes may affect the nutrition of the host in several ways. They influence the amounts of glucose available to the animal. It was previously calculated (McAllan \& Smith, 1974) that for a calf receiving diets containing $900 \mathrm{~g}$ cereal $/ \mathrm{kg}$ DM about $65 \mathrm{~g}$ glucose $/ \mathrm{d}$ was supplied by the bacterial $\alpha$-dextran. This, although low by comparison with energy 
supplied as volatile fatty acids, may be of importance since it avoids the use of glucose synthetic pathways which may sometimes be limiting. A more transient increase such as that found with the dried forage and soluble sugar diet would be expected to provide less glucose to the animal. Differences in $\alpha$-dextran accumulation also influence the efficiency with which the rumen bacteria will synthesize other nutrients from a given energy supply. If bacterial synthetic effort is directed to polysaccharide synthesis then in the short term less protein synthesis is likely to occur. This was recognized as being likely to affect the efficiency of microbial protein synthesis in the rumen by Walker \& Nader (1970) on the basis of in vitro experiments. The results of the present experiment indicate that diversion of synthetic effort from protein to polysaccharide synthesis occurred, to differing extents, for the various diets studied. Bacterial $\alpha-$ dextran, however, may provide a potential supply of energy for microbial protein synthesis over a longer period. It is not certain to what extent storage polysaccharide is used only by the organisms storing it, but recycling undoubtedly occurs to some extent (Cheng, Hironaka, Roberts \& Costerton, 1973). The overall efficiency of microbial protein synthesis depends upon a balance between rates of supply of energy and a suitable $\mathrm{N}$ source. Thus, for example, urea is rapidly converted to ammonia in the rumen but much of this ammonia may remain in the rumen for many hours (Smith, 1975). It can, however, only be used effectively for protein synthesis if enough energy is available also. It appears from the present results that starch diets lead to a more prolonged period of bacterial polysaccharide accumulation than diets containing soluble sugars. This may be one reason why starch diets lead to more effective utilization of urea than diets containing most energy in the form of soluble sugars (Oldham, Swan \& Lewis, 1973).

The samples appeared to contain remarkably high amounts of ash compared to values generally quoted for bacteria (e.g. Henderickx, Demeyer \& Van Nevel, 1972) but were, however, similar to those reported for rumen bacteria in our earlier experiments (Smith \& McAllan, I973) and by Bird (r973). The composition of the ash has only been partially determined. It showed little variation between different diets or between samples taken at different times except for $\mathrm{Na}$ and $\mathrm{K}$ contents. These tended to vary inversely against each other and the $\mathrm{Na}$ to $\mathrm{K}$ ratio fell markedly between before feed and after feed samples.

We thank Dr H. L. Buttle and Mr S. Watson for carrying out all surgical operations, Mrs S. J. Askew for the care and maintenance of the calves and Mr R. J. Merry for skilled technical assistance.

\section{REFERENCES}

Bird, P. R. (1973). Aust. F. Biol. Sci. 26, 1429.

Bryant, M. P. (r973). Fedn Proc. Fedn Am. Socs exp. Biol. 32, 1809.

Cheng, K.-J., Hironaka, R., Roberts, D. W. A. \& Costerton, J. W. (1973). Can. F. Microbiol. r9, 150 .

Coleman, G. S. (1964). F. gen. Microbiol. 37, 209.

Coleman, G. S. (1972). F. gen. Microbiol. 7 I, I I7.

Czerkawski, J. W. (1975). Proc. Nutr. Soc. 34, 62A.

Eadie, J. M. \& Gill, J. C. (1971). Br. F. Nutr. 26, 155.

Eadie, J. M. \& Hobson, P. N. (1962). Nature, Lond. x93, 503. 
Fiske, C. H. \& Subarrow, Y. (1925). \%. biol. Chem. 66, 375.

Henderickx, H. K., Demeyer, D. I. \& Van Nevel, C. J. (1972). In Tracer Studies on Non-protein Nitrogen for Ruminants, p. 57. Vienna: I.E.A.E.

Herbert, D. (1961). Symp. Soc. gen. Microbiol. rr, 391.

Hobson, P. N. (1965). Y. gen. Microbiol. 38, 167.

Hoogenraad, N. J. \& Hird, F. J. R. (1970). Br. F. Nutr. 24, I19.

Jouany, J.-P. \& Thivend, P. (1972). Ann. Biol. anim. Biochim. Biophys. 12, 673.

Kurihara, Y., Eadie, J. M., Hobson, P. N. \& Mann, S. O. (1968). F. gen Microbiol. 51, 267.

McAllan, A. B. \& Smith, R. H. (1974). Br. J. Nutr. 3r, 77.

McAllan, A. B. \& Smith, R. H. (1976). F. Agric. Sci., Camb. 86, 639.

Oldham, J. D., Swan, H. \& Lewis, D. (1973). Proc. Nutr. Soc. 32, 89A.

Purser, D. B. (1970). Fedn Proc. Fedn Am. Socs exp. Biol. 29, 5 I.

Smith, R. H. (1962). Biochem. F. 83, 15 I.

Smith, R. H. (1975). IV International Symposium on Ruminant Physiology, p. I10 [I. W. McDonald, editor]. Sydney, Australia.

Smith, R. H. \& McAllan, A. B. (1966). Br. J. Nutr. 20, 703.

Smith, R. H. \& McAllan, A. B. (1970). Br. F. Nutr. 24, 545.

Smith, R. H. \& McAllan, A. B. (197I). In Automation in Analytical Chemistry (Technicon International Symposium, 1969), p. 207. Basingstoke, Hants: Technicon Instruments Company Ltd.

Smith, R. H. \& McAllan, A. B. (r 973). Proc. Nutr. Soc. 32, 9A.

Smith, R. H. \& McAllan, A. B. (I974). Br. F. Nutr. 3r, 27.

Walker, D. J. \& Nader, C. J. (1970). Aust. F. agric. Res, 12, 65I. 